\title{
SITUATION MOTIVES IN EUROPEAN AND CENTRAL ASIAN EPICS
}

\author{
Sapaeva Bibijon Rustamovna \\ English Teacher, English language and literature department, Urgench State University \\ Saparbaeva Gulandom Masharipovna \\ English Teacher, Roman-German philology department, Urgench State University, Uzbekistan,
}

Article DOI: $\underline{\text { https://doi.org/10.36713/epra4068 }}$

\begin{abstract}
The article reveals the comparative study of situation motives in European and Central Asian epics. It provides the detailed information about similar motives, in which an extraordinary and adventurous life styles of epic heroes, their courage and undergoing a risky occasions.
\end{abstract}

KEY WORDS: epic characters, situation motives, magical birth, comparative study of epics, European and Central Asian epics, adventurous life, courage and proud.

\section{DISCUSSION}

Conception of motive plays an immense role in the world literature and it can be used for different reasons by the authors. Actually the motives are considered as a very important tool in order to create a theme and a particular tone of the play in the literary works.

In its turn, the repetition of the words is essential factor of the motive, increasing its significance and makes the target play to be fully grasped by the reader.

In fact, the term "motive" is reckoned as a symbolic description or notion, which can be frequently displayed in the works, and meanwhile it may comprise an allegory, sounds, words, actions or ideas. Likewise, the word motive (moh-teef)was taken from the french word "motif" and it means "pattern or sample".

So, the motives serve to maintain the literary works with a consecutive patterns or events. For instance, the descriptions of a red dress or feeling guilty or the other situations, related with the description of songs about an epic hero, which is felt during the narration are considered as a significant form of the motive. It may enhance the chance to the author to dispose or create a well-structured poetic works.

For example, the descriptions related to an extraordinary birth of the epic hero and his possessions such as a loyal horse and fighting tools are mostly demonstrated in mutually identical narrative situations in the world folk epic poems. As X.G.Ko 'rogli points out that such kind of identical motives appear due to different literal-cultural relations and influences. They are represented in the ethno-genetic, socio-political, ideological and historical forms.

If we study comparatively identical motives in the epics such as old Anglo-Saxons' epic "Beowulf", "Shahnameh" by Firdavsi, the Accadians' epic "Gilgamish" or the French epic "The Song of Roland", one may observe such kind of similar situational motives in these world folk epics.

The motives of an extraordinary birth of the main characters, hunting, travelling and magic sleeping are known as wide spread situation motives in European and Central Asian epic-poems.

As the motive of magical birth of an epic character is common in world folk epics, which we may observe a peculiar similiarities in all epic-poems. 


\section{SJIF Impact Factor: 6.260| ISI I.F.Value:1.241| Journal DOI: 10.36713/epra2016 ISSN: 2455-7838(Online) EPRA International Journal of Research and Development (IJRD)}

It is commonly observed that the phenomenon like the birth of Gorogli (the boy who was born in the tomb) due to other Turkic epics and Edigo, whose mother was an angel and was nurtured by the bird Semurg. Prediction of an epic another epic character Rustam as a great ruler, when he came to life. In turn, it should be mentioned that, this phenomenon is an archaic epic and it is related mostly to mythologies.

However, the living period of Roland, who was the main epic character in French folk epics, correlates to more developed period of society. That's why, it may seem a bit strange to find examples about above-mentioned motives in this epic.

So, we can say that an extraordinary birth-related phenomenon is not peculiar to this epic. But one may read and come accross such kind of unique and unusual circumstances about his further life.

According to an Islandic description of the epic "The Song of Roland", an hour later after his birth, Roland asks a iron-knobstick of 300 $\operatorname{pud}(1 \mathrm{pud}=16.8 \mathrm{~kg})$, an iron shield and a steel-sword. Such kind of exaggerated descriptions are common in world folk epics. Particularly it is more highlighted about the scenes of physical strength of an epic character. Meanwhile, the motive of travelling in search of adventure enriched the narration of epics in both European and Central Asian epics and show us that the courage and willpower of main characters are tested under difficult circumstances. For instance, according to the Accadian epic "Gilgamesh" departure of Gilgamesh in order to find a magic flower to achieve eternal life, which rejuvinates the elderly; or the adventure of Beowulf in the AngloSaxon epic "Beowulf" about his adventurous travel to help to Hrothgar, a Danish king; or another description of about an epic hero Rustam in the epic "Shahnameh" by Firdavsiy and his eagerness to experience several magic adventures can be vivid examples of getting tested in life's trails. These epic heroes had indeed a super power and courage.

The following extract from the epic "Shahnameh" is a crucial example to our above mentioned statements (from Uzbek into English):

Dedi o'g 'li Rustam- sor lochiniga

«bu kun qilich sig`may qoldi qiniga.

Nozlanish kelishmas bizlarga bu choq,

Toj uchun tanimiz parvarish qilmoq.

Ajdaxo domida podshohi jahon,

Eroniy boshida g`am alvon-alvon. [p327]

The Crown prince Rustam, to his loyal horse, said:

"My sword is now out of its sheath,

Titivating our body and pouring

To suit the throne is not for us.

Dragon's chela chased the world king,

Sorrow is blinking on Iranian land. [p327]
This is another example of comparatively analyzed situation motive:

- The motive of not to obey to the enemy in "The Song of Roland" and "Shahnameh"., staying proudly not avoiding themselves from a desperate situation can be observed in the epics even in case of realizing his inevitable failure or loss.

As a result of comparative analytical studies of the epics "The Song of Roland" and "Shahnameh" (an epic about the Iranian kings), We identified the following identical situation motives in the description of the main epic heroes Roland and Rustam in the scene of Roland's fight with the Spanish warriors at Roncesvales and Rustam's fight against Iranian warriors.

Meanwhile the plan of this war made up by Roland's stepfather Ganelon and the Spanish king Marsilla against the step son Roland. Because Roland was a brave knight of the king Karl the Great and the king trusted and supported him deeply because of his outstanding intelligence and courage among his effectives.

Likewise, in order to kill Roland, while he was staying in Spain with his few troops, the king Marsilla made an attack to the Frank soldiers and as a result, Roland's loyal friend Oliver and other militaries were killed at the battle. Unfortunately, Roland's extreme pride and obstinacy, and not following to his friends' advice caused the failure of Frank soldiers. Because, when they advised Roland to call for more military aid from the king Karl, he appealed his soldiers to fight bravely instead of asking for help because of being too proud and stubborn (From English into Uzbek):

(1045) Lords of the Franks, God keep you in valour!

So hold your ground, we be not overborne!"

Then say the Franks "Shame take him that goes off:

If we must die, then perish one and all."

We can observe such kind of proud and firmness in his decree in another epic "Siyovush", who was the son-in-law of Afrasiab, and established the city Siyovushghird and gained an immense respect or appreciation of his folkmen by his intelligence, humbleness and courage. Unfortunately, he was the victim of conspiracy of his advisor Garsevaz because of his envy to Siyovush. He had accused Siyovush of having treachery to Afrasiab (according to hid stepmother's slander, king Kaikovus broke the relationship with Siyovush).

As a result, Afrasiab commanded Garsevaz to bring Siyovush back, but cunning Garsevaz abused Afrasiab to Siyovush. When he 


\section{SJIF Impact Factor: 6.260| ISI I.F.Value:1.241| Journal DOI: 10.36713/epra2016 ISSN: 2455-7838(Online) EPRA International Journal of Research and Development (IJRD)}

returned back, he pretended by saying that Siyovush rejected to go back and informed that he was in good terms with the Iranians, so he was going to attack soon with the help of them.

Meanwhile, Siyovush saw a predictor horrible dream about an upcoming distress, he left for Iran with his militarians. Unfortunately on the halfway his fatherin-law Afrasiab obstacled their way. In this case, Siyovush ordered his soldiers not to attack against them. But under an extreme anger, Afrasiab ordered to catch and then they killed an innocent Siyovush.

In Uzbek: Siyovush xudoga qilardi nola,

«Ey gardishi falak, senga havola.

Bukun shul Garsevaz qo'llarida xor,

Tuproqqa qorilib, yig`lab zoru-zor.

Yoturman, g`amdan past arjumand boshim,

Zor yig 'laguvchim yo`q, yo`q qarindoshim.

English equivalent translation:

Siyovush pleaded, cried to God

"Oh my fate is in your hand,my greatest Lord,

Today in Garsevas's paw I'm foul,

Weeping bitterly, polluted in the soil,

with valueble head bowed down with sorrow, I am lying down

I've nobody to cry, nobody to moun.

The count Rolland is of such pride and force

He'll never yield to man of woman born;

Let's aim at him, then leave him on the spot!"

2155 And aim they did: with arrows long and short,

Lances and spears and feathered javelots;

Count Rolland's shield they've broken through and bored,

The woven mail have from his hauberk torn,

But not himself, they've never touched his corse;

It is clear from the comparative analyses, these two epics testify that in the climax the main heroes were so proudy and stubborn and rejected to ask for help even when they are in trouble (for example, Roland could have appealed king's troops to the fight; at the same time, Siyovush could have asked for the reason why he was sentenced to the death and justified that he was totally innocent) and on the other hand, one can be certain that both of them had a firm commitment and courage, even it leads to their death.

This, in turn, exceeds the main points of the plot of the epic and maintains the attention of the reader till the end of the play inspite of the death of main characters.

According to the ancient Turkic mythology, there existed two heavenly heroes (images), called Angur and Tangur and in the legend it is depicted that the movements of heavenly bodies were carried out by two of them. Due to that myth, our galaxy appeared because of stucking their canes tot he layer of the sky, while they were fighting with each other.

Such kind of long canes is not only an imaginary fiction, but also is one of the ancient legendary motives, which is related with mythological notion about the tool of creation of the world.

According to A.M.Sagalayev the first primitive tool was the «crutch», which was depicted in the cosmogonic myths by the people lived in the Western-Syberia.

That crutch was interpreted as the main "working tool" of the Goddes, which can fix the defects in the universe. To open the way to the heaven the crutch is stuck tot he sky, to go to the underearth world the crutch is stuck to the gropund by the God. So, mythoepic image ,crutch“" was considered as a symbol of creating celetial bodies in the myth "Angur and Tangur". Likewise, in the French epic "The Song of Roland", according to the plot oft he epic, the king Karl the Great handed a crutch and a pair of gloves to his courtier Ganelon as a symbol of confidence and a good journey, while sending him as an ambassador to the Spanish king:

\section{XXV}

His right hand glove that Emperour holds out; But the count Guenes elsewhere would fain be found; When he should take, it falls upon the ground.

Murmur the Franks: "God! What may that mean now?

335 By this message great loss shall come about."

"Lordings," says Guene, "You'll soon have news enow."

\section{XXVI}

"Now," Guenes said, "give me your orders, Sire;

Since I must go, why need I linger, I?"

Then said the King "In Jesu's Name and mine!" 340 With his right hand he has absolved and signed, Then to his care the wand and brief confides.

Unfortunately he drops the royal gifts given by the king down unexpectedly. At that time, dropping something unexpectedly meant a nuisance due to the folk's superstition and as a result the courtiers got into trouble that something bad is being expected to happen by Ganelon.

This situation motive being related with the folk superstition that was considered as a bad indication according to the people's belief in the past. At the same time that crutch was perceived as «a tool to control » of the God in the Turkic folk epics in order to keep the universe in balance.

In conclusion, it should be mentioned that not only a majestic power and courage of the main epic heroes, whose influence are felt in whole events of the epic in order to demonstrate their particular distinguishing character, predisposition and an 
extraordinary abilities are taken to the reader's focus, but also another mythological characters or personages have an undeniable significance in these epics. It is known from the comparative study, that even if above-mentioned European and Central Asian epic poems were composed at different periods and the development of identical events is observed in these epics, it does not mean that the existing events were not copied from each other. On the contrary, one can observe and realize that such kind of similar motives were formed because of the existence of a particular lifetyles, state systems, traditions, religious commitments and mutul relations of each folk or nation. Actual events are seen integratedly in combination with a literal compostion, imaginary notion and mythological suppositions, by displaying an analytical details about an inner world or humane feelings of the heroes, not only reflecting the sequence of the events.

Hence, the main epic heroes in these epic poems are described as a heroic character, who is reasonable and has a sense of divine sensitivity by being distinguished from other ordinary people due to their extraordinary birth, strength and courage.

Meanwhile, the main feature of an ancient folk epics is that there is no any conflict between the epic hero and society (for example, tribe, clan, nation or nativeland) and he acts as a representative and defender of his folkmen, as well as his countrymen admit his honest endeavour.

Supposing the life without any sorrow or conflicts is considered as a general feature of an old epics. The heroine actions of legendary french king Karl the Great and his loyal knight Roland can be a vivid example to our opinion.

As several types of similiarities exist in different folk epics, each of them can be characterized due to their peculiar distinctive features.

So, except from the comparative-linguistic method, another "comparative-typological method", being one of the widespread and effective methods gains a significant role in investigating folk epics.

\section{REFERENCES}

1. Firdavsiy.Shahnameh. Literature and Art. Publish House named after Gafur Gulam. In Uzbek, Tashkent. 1975

2. Ro'zmetov.H.Q. From the Experience of Comparative Studies of French and Turkic Folk Epic. In Uzbek.Science Academy of the Republic of Uzbekistan, 2009

3. The Song of Roland. Online Medieval and Classical Library Release. 1995

4. Unknown Author. Beowulf. Translated by Burton Rafeel

5. Abdurashid Abdurahmonov.Ancient Period of Turkic Literature. In Uzbek. Toshkent, Yangi asr avlodi, 2005 